Historic, Archive Document

Do not assume content reflects current scientific knowledge, policies, or practices. 



\section{Choicest Strawberries}

HOW TO GROW AND ENJOY THEM

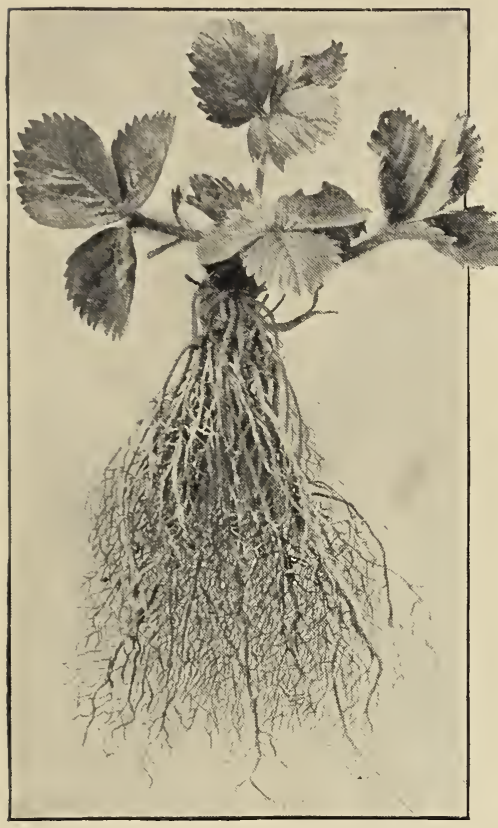

7 HERE should be room in even the smallest garden for a Strawberry bed. Considering 1 the ease with which these most delicious fruits can be grown in almost any soil throughout the season, with the help of the everbearing varieties, the gardener who is not growing them is depriving himself of a genuine succession of delights.

Strawberries give the greatest yield and the Iargest berries when grown in rich soil; hence no pains should be spared in preparing the bed carefully before planting, by digging or plowing deeply, and turning under, a liberal supply of well-rotted manure. At fruiting-time a top dressing of ground bone will be beneficial.

Strawberry plants should be set out in rows 2 feet apart and the plants a foot apart, cutting off all runners as they appear. For field culture the rows should be $31 / 2$ feet apart, then cultivation can be made with horse and hoe harrow. The varieties we offer are aII perfect flowering and therefore need no association with any other variety for perfect fruiting.

Save time, gain crops by starting your garden with

\section{Hunt's Perfection Pot-Grown Strawberry Plants}

By setting out pot-grown plants you practically eliminate the chance of losing plants no matter how Iate they are set out, or how dry the season. Our pot-grown Strawberry plants are vigorous young specimens, grown in pots, and shipped with ample earth about the weIIdeveloped roots. Such plants take hold immediately, and a heavy crop is assured the following season.

Shipping season starts July 15 until October. We recommend as early planting as possible to enable the plants to get established before the advent of winter.

\section{The Everbearing Strawberries}

The everbearing varieties of Strawberries, frequently termed "fall-bearing," have decided merit. In addition to bearing a good crop in Iate summer and autumn, they also give a heavy crop of fruit as early as June. In order to be sure of a good fall crop, remove aII blossoms from the plant as they appear from the first to the middle of July. Aside from this, their culture is exactly the-same as the standard varieties described previously. We offer below three sorts that deserve to be most widely grown and which have proven to be the most successful under all conditions.

Champion. This variety, a seedling of Superb, produces dark crimson, smooth, and sweet-flavored berries. One of the most prolific sorts. Pot-grown plants, $\$ 1.50$ per doz., $\$ 10$ per 100.

Progressive. The plants are vigorous in habit with large, clean leaves. They multiply better than most fall-bearing sorts and yield profusely. The berries are smooth and uniform in size, deep crimson in color, and of superb quality. Pot-grown plants, \$1.25 per doz., \$8 per 100 .

Superb. The best-known and most largely planted of the fall-bearing sorts. The berries are almost round and larger than those of the Progressive. The smooth, dark crimson fruits are produced well above the dark green foliage. An exceedingly good variety. Pot-grown plants, $\$ 1.25$ per doz., $\$ 8$ per 100 . SPECIAL OFFER. To encourage the planting of Everbearing Strawberries, we will send one 


\title{
Standard Varieties of Strawberries
}

\author{
Pot-grown Plants
}

\section{NOVELTIES FOR 1925}

DELICIOUS. A new medium to Iate variety, producing enormous crops of berries that are true to name, "Delicious." Originated in New York State and produces best results from Philadelphia northward. \$1.50 per doz., \$10 per 100.

CHARLES I. Extra early, being one of the first varieties to ripen its fruit. A big cropper of evenly shaped, well-colored berries. Because of its extra-heavy root system it will withstand drought better than almost any other kind. $\$ 1.50$ per doz., $\$ 10$ per 100 .

SPECIAL OFFER. One dozen each of the above sterling novelties for $\$ 2.75$

\section{GENERAL LIST}

Barrymore. The bluntly conical berries are of large size, beautiful, firm, meaty, and of rich and sugary quality. The color is dark crimson (which it holds unchanged after being picked), with glossy surface; the flesh is deep red. Midseason to late. $\$ 1$ per doz., $\$ 7.50$ per $100, \$ 70$ per 1,000 .

Brandywine. Bears great quantities of large, bright crimson berries that are firm enough for shipment, and of good quality. Demands rich soil. Midseason. \$1 per doz., $\$ 7.50$ per $100, \$ 70$ per 1,000.

Chesapeake. Where properly grown, on rich soil, this berry is well-nigh perfect. The berries are uniform in size and shape, mostly heart-shaped; the color is bright crimson and the flesh firm and of excellent quality. Midseason to Iate. $\$ 1.25$ per doz., $\$ 8$ per $100, \$ 75$ per 1,000 .

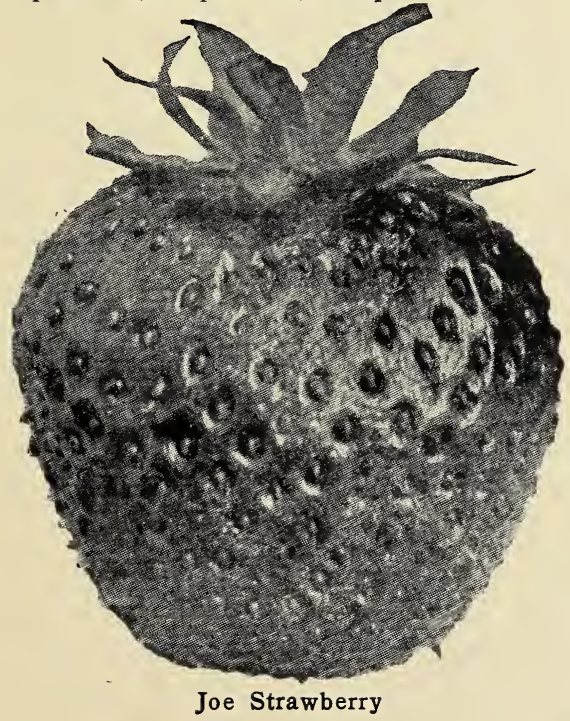

Gandy. Introduced over thirty years ago and still grown commercially to a greater extent than probably any other sort. The texture is of the firmest and the color a bright flame. Of large size and is late to very late in ripening. $\$ 1$ per doz., $\$ 7.50$ per $100, \$ 70$ per 1,000 .

Glen Mary. An old popular favorite, especially through the Middle Atlantic and New England States where it does best. Because of its superb quality and tremendous productivity it is, without doubt, one of the most satisfactory varieties to grow. The large, deep rich red, broadly conical berries are very attractive, bringing top prices until the end of the season. Should be planted near some good pollenizer such as Joe. $\$ 1$ per doz., $\$ 7.50$ per $100, \$ 70$ per 1,000 .

Joe (Big Joe). A midseason to late variety, fully up to Chesapeake in size, firmness, and yield, and superior to it in flavor and color. It also succeeds in a great variety of soils. This is a berry that will not disappoint. The plants are disease-resistant. Our stock of this variety is extra choice. $\$ 1$ per doz., $\$ 7.50$ per 100 , $\$ 70$ per 1,000 .

Judith. The large, well-flavored fruit maintains its size uniformly throughout the season. The dark red berries are large, pointed in shape, and of a deep red color throughout, to the core. The berries are firm and full of juice, a combination that makes this variety ideal for both home and market garden. The berries are borne in large clusters, while the bright green foliage and the strong plants cause the fruits to stand out in beautiful contrast. $\$ 1.25$ per doz., $\$ 8$ per $100, \$ 75$ per 1,000 . 


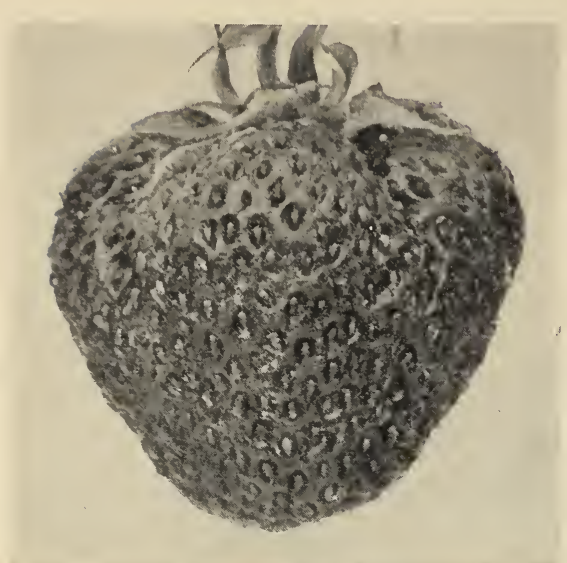

Success Strawberry

Lupton. Berries are Iarge, bluntly conicaI, bright flame-colored, glossy, and retain their color after being picked. They are also very firm, hence splendid for market. Practically ideal in growth of plant and vigor. $\$ 1$ per doz., $\$ 7.50$ per $100, \$ 70$ per 1,000 .

Marshall. Still very popular in the East. The plant, of vigorous growth, with clean healthy foliage, is very productive under high culture. The beautiful large berries are of extremely good quality and meaty texture. Midseason. $\$ 1$ per doz., $\$ 7.50$ per $100, \$ 70$ per 1,000 .

New York. Another "quality" berry ripening in midseason. It is, in many respects, very much like MarshaII, but appears to give better results under less exacting soil conditions. $\$ 1$ per doz., $\$ 7.50$ per $100, \$ 70$ per 1,000 .

Premier. Excelled by no early variety. It succeeds on almost all sorts of solls (if well drained) and throughout a large section of the country. Produces in vast quantities berries of good size, attractive appearance, and excellent quality. \$1 per doz., $\$ 7.50$ per $100, \$ 70$ per 1,000 .

Royal Sovereign. A well-known English variety that is used here principally for forcing, but which does equally well outdoors. Distinct in habit, shape, and flavor. Very heavy cropper. \$12 per 100.

Senator Dunlap. Of good quality, for a firm berry, and uniform in color and shape. Largely planted for market and found very profitable. It is a second-early to midseason variety. $\$ 1$ per doz., $\$ 7.50$ per $100, \$ 70$ per 1,000 .
Sharpless. A variety that fruits rather late in the season, and a good old sort that still "holds its own" with the best of them. It is a good healthy grower and produces handsome large berries of fine quality. $\$ 1$ per doz., $\$ 7.50$ per $100, \$ 70$ per 1,000 .

Stevens' Late Champion. Like its parent, Gandy, it ripens late and is similar in many respects, but the berries are not so uniform in size and shape. Excellent for canning, since it will hold its shape and retain its flavor. It is one of the most prolific and valuable of the late varieties. $\$ 1$ per doz., $\$ 7.50$ per $100, \$ 70$ per 1,000 .

Success. AII things considered, this is one of the best early varieties, both for the home garden and nearby market. Berries slightly oblong, with blunt end, bright scarlet or flame color, quite large, and uniform in size, color, and shape. Plants are vigorous, healthy, and very prolific. $\$ 1$ per doz., $\$ 7.50$ per $100, \$ 70$ per 1,000 .

William Belt. The plant is vigorous, though not a rampant grower, succeeds on almost all soils, invariably yields heavily, and the berries are always of large size and highest quality. Its flesh is solid and deep crimson in color, and the blossoms are large, with abundance of pollen. It begins to ripen quite early and continues until almost the close of the season, the last berries being Iarge, handsome, and full-flavored. $\$ 1$ per doz., $\$ 7.50$ per 100 , $\$ 70$ per 1,000 .

Late summer planting of Hunt's Superb Strawberry Plants in heavily fertilized ground insures a good crop of fruit next spring.

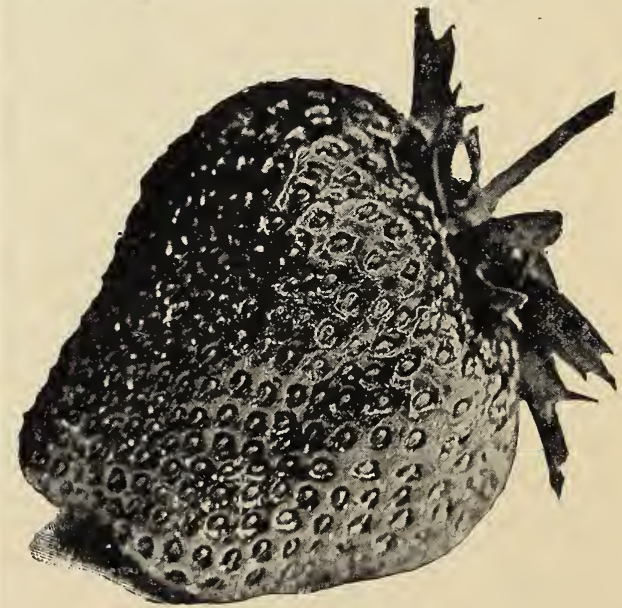

Royal Sovereign Strawberry 
Telephone Walker $2146 \quad$ ORDER SHEET Date

\section{William M. Hunt \& Company, Inc.} 148 Chambers Street, New York

Name

P. O. Box, Street

or Rural Delivery

Post Office

County State

Station or

Express Office

Only if different from Post Office

Send by

State if wanted by Mail, Express or Freight

Superintendent or Gardener

That we may enter for Catalogs

\begin{tabular}{|c|c|}
\hline O. N. & \\
\hline Stamps & \\
\hline Cash & \\
\hline Checks & \\
\hline M. Order & \\
\hline Cr. Memo. & \\
\hline V.Seeds & \\
\hline Fl. Seeds_ & \\
\hline Bulbs___ & \\
\hline Sundries & \\
\hline Plants & \\
\hline $\begin{array}{l}\text { Customers will please } \\
\text { not write in this space }\end{array}$ & \\
\hline
\end{tabular}

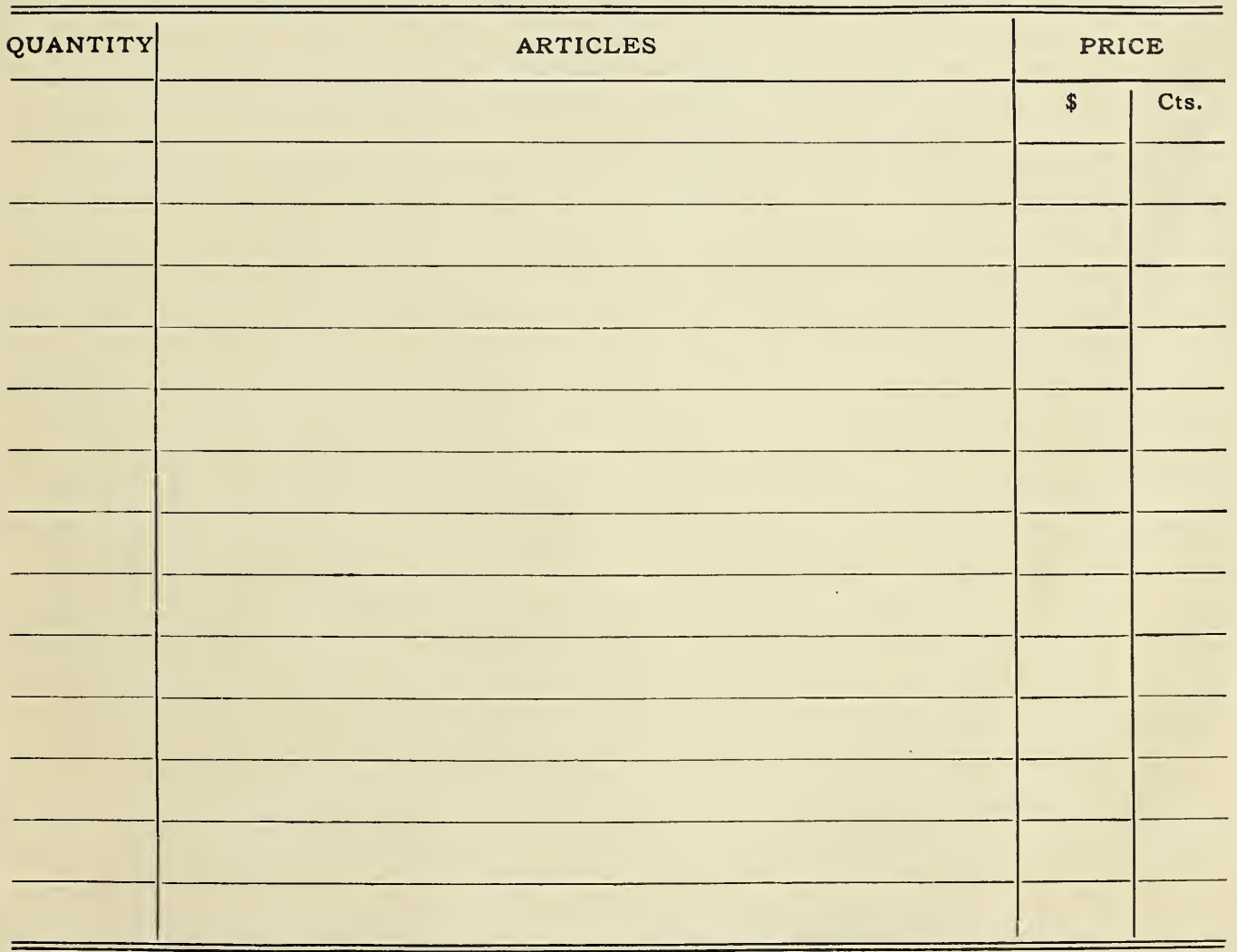




\section{SMALL FRUITS}

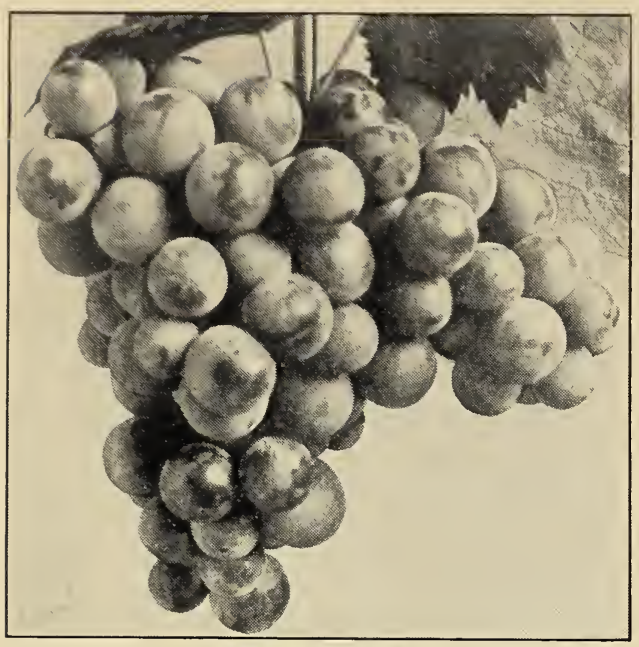

Catawba Grapes

\section{GRAPES}

\section{For the Home Gardens}

Orders booked now will be shipped in October.

Agawam. Deep red, almost maroon. Large loose bunch; berries large, meaty with rich aromatic flavor. Strong twoyear plants, $60 \mathrm{cts}$. each, $\$ 6$ per doz.

Campbell's Early. Early-ripening black Grape. Produces large bunches of superb fruit. Two-year plants, 75 cts. each, $\$ 8$ per doz.

Catawba. Standard red Grape. Vigorous, hardy, and productive. Clusters Iarge, long, and broad. Berries of medium size. Two-year plants, $60 \mathrm{cts}$. each, $\$ 6$ per doz.

Concord. Best-known and most popular variety. Succeeds almost everywhere. Large black berries are borne in large bunches. Two-year plants, $50 \mathrm{cts}$. each, $\$ 5$ per doz.

Niagara. Popular white variety. Cluster Iarge and compact. Ripens in midseason with Concord. Two-year plants, 50 cts. each, $\$ 5$ per doz.

\section{CURRANTS}

\section{The Ideal Fruit for Jellies}

A cool, moist location is best for these fruits. They succeed admirably when planted by a stone wall or fence. Keep the ground mellow and free from weeds and grass, using fertilizer plentifully for currants are heavy feeders. The buds start so early in the spring, that better results will be had by faIl planting. October delivery.

Fay's Prolific. Bunch and berry large, bright red, and sparkling. A regular and prolific bearer. Two-year plants, 60 cts. each, $\$ 6$ per doz.

President Wilder. Produces, late in the season, very large, bright red berries that are juicy and of high quality. Two-year plants, 60 cts. each, $\$ 6$ per doz.

Red Cross. This is reputed to be the sweetest of all Currants. It is an exceptionally healthy and vigorous grower. Produces immense crops of good-sized sparkling red berries in large clusters. Two-year plants, 60 cts. each, \$6 per doz.

\section{GOOSEBERRIES}

\section{The Berry for Good Pies}

Gooseberries may be grown in America just as easily as in Europe, where almost every cottage garden has its planting of Gooseberry bushes. No particular garden skill is necessary to raise them. The soil should be weIl enriched and the plants should be given ordinary garden culture. October delivery.

Oregon Champion. Distinct from all others. The plant is of a rather slender growth and is not a very strong grower, but it produces berries that are pale amber when fully ripe and of excellent quality and good size. Two-year plants, $\$ 1$ each, $\$ 9$ per doz.

Carrie. This is a very strong grower and highly productive. When ripe it is maroon in color and of good quality, though the berries are rather small. Two-year plants, 50 cts. each, $\$ 5$ per doz.

Downing. Perhaps the most popular variety. The berries are pale green and of large size and good quality. Two-year plants, 60 cts. each, \$6 per doz.

\section{BLUEBERRIES}

There is a great deal of difference between the common Blueberry and the cultivated varieties, not only in size but also in flavor and productiveness. The large, luscious berries of the improved sorts average one-half inch in diameter and have seeds so small as to be almost unnoticeable. The plants require an acid soil and are most successfully grown in damp locations, but never soggy. Do not use lime or stable manure, but keep up the acidity of the soil by heavy mulches of freshly fallen leaves each year, and supply plant food by the addition of weIlrotted leaves. $\$ 1$ each, $\$ 8.50$ per doz. 
. 


\section{BLACKBERRIES}

There are, indeed, few greater delights than to be able to go into one's garden and pick big, shiny beauties by the panful, to be converted into delicious jams, jellies, and pies, or served, just as they are, for breakfast or as dessert. In field-culture, plant in rows from 5 to 7 feet apart (according to the vigor of the variety) and 3 feet apart in the rows. In the garden, plant in rows 5 feet apart and the plants 3 feet apart in the rows. October delivery.

Eldorado. Vcry popular, cspecially throughout the North, on account of its extreme hardiness and vigor. Berries are medium size, jet-black, and very sweet. Fruits early to midseason. Transplanted canes \$2 per doz., \$8 per 100 .

Taylor. A most profitable late variety. Clean, healthy foliage with berries of good size and very productive. Transplanted plants, $\$ 1.50$ per doz., $\$ 7.50$ per 100 .

Ward. A very popular variety, especially in New Jersey. The canes are of strong growth, quite hardy, and yield a heavy crop of large, handsome berries, that always command best prices. Transplanted plants, \$2 per doz., \$8 per 100 .

\section{LOGANBERRIES}

This is rather a unique fruit, being a cross between the raspberry and blackberry, yet it is distinct from either. The flavor is delicious, differing from any other fruit and pleases everybody as a dessert. It ripens about the end of the strawberry season and in advance of all but the earliest raspberries, therefore it comes into use at the time when it is most appreciated. Extra-heavy fruiting plants, $\$ 1$ each, $\$ 9$ per doz.

\section{RASPBERRIES}

\section{October delivery}

St. Regis. This is a well-known everbearing variety and will produce berries of good quality for four months. Heavy fruiting plants, $\$ 3.50$ per doz., $\$ 17.50$ per 100 .

La France. This variety is of recent introduction and has proved to be the best everbearing Raspberry grown. Is extremely hardy, reaches a height of 9 feet, and the berries are deep pink, juicy, and of delicious flavor. The fully developed fruits are twice the size of the average Raspberry. Extra-selected plants, \$6 per doz., \$45 per 100.

Cuthbert. Berries are large size, deep crimson, firm, and of high quality, being rich and spicy. Ripens in midseason until late, and succeeds in any location. Strong plants, $\$ 2$ per doz., $\$ 12.50$ per 100 .

White Queen. This variety, our own introduction, was offered for the first time in 1920 and has exceeded our highest expectations. Bears an abundance of almost white fruits from August until weIl into November. The Iarge, firm berries are free of seeds, acid, of exquisite flavor and aroma. Plants attain a height of 6 feet. We suggest a light covering or burying the plants a foot deep under the soil, for protection from frost during winter. $\$ 6.50$ per cloz., $\$ 50$ per 100 .

\section{Black \\ Raspberries}

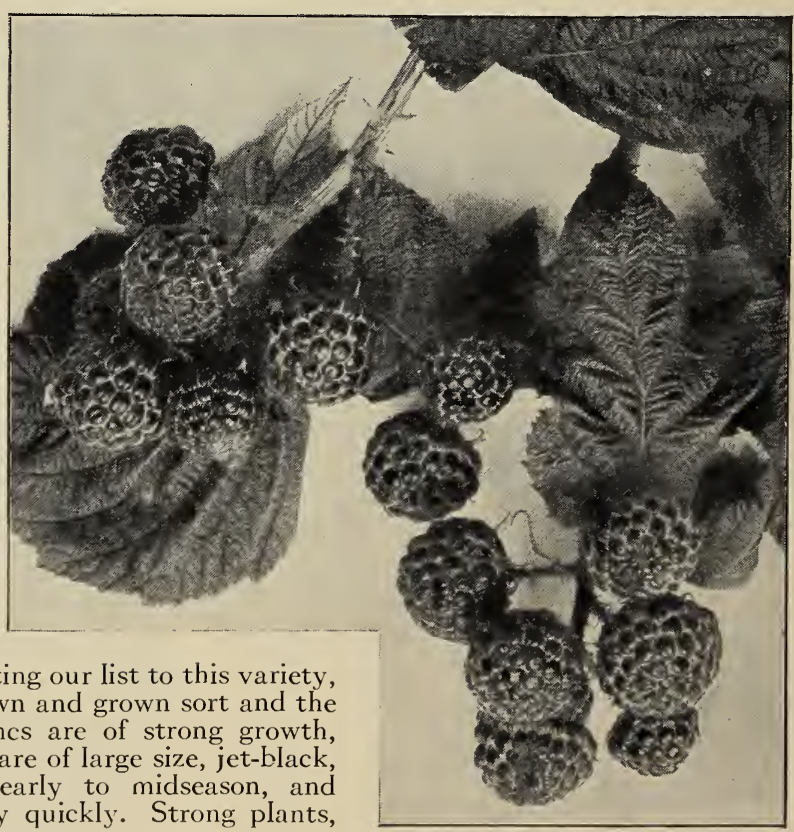

Kansas Blackcap Raspberries 